\title{
Assessing a National Work Health and Safety Policy Intervention using the Psychosocial Safety Climate Framework
}

Rachael E. Potter - Asia Pacific Centre for Work Health and Safety

The University of South Australia

Professor Maureen F. Dollard - Asia Pacific Centre for Work Health and Safety

The University of South Australia

Mikaela S. Owen - Asia Pacific Centre for Work Health and Safety

The University of South Australia

Dr. Valerie O'Keeffe - Asia Pacific Centre for Work Health and Safety

The University of South Australia

Tessa Bailey - Asia Pacific Centre for Work Health and Safety

The University of South Australia

Professor Stavroula Leka - Centre for Organizational Health \& Development The University of Nottingham

This paper is intended for the journal 'Safety Science' special edition on Promoting a Healthy Psychosocial Work Environment in Times of Change 


\begin{abstract}
Despite support for work health and safety (WHS) policy interventions, the evaluation of their effectiveness has been overlooked. As such, many important policy developments have not been assessed for their impact within jurisdictions and organisations. We addressed this research gap by using the Psychosocial Safety Climate (PSC) framework, theory, measurement tool - the PSC-12, and benchmarks - to investigate the impact of a WHS policy intervention, across Australian jurisdictions, that standardised policy approaches (i.e. harmonisation) and legislated the protection of psychological health. PSC refers to a facet of organisational climate that relates to psychological health and safety and is a predictor of job design and employee health. We investigated perceived organisational PSC across jurisdictions, across time, and contrasted effects between those that did (harmonised) and did not (non-harmonised) adopt the policy. Results showed Time X Group effects for the global PSC measure, indicating a significant difference over time between the harmonised and non-harmonised jurisdictions. Specifically, PSC levels significantly decreased in the non-harmonised jurisdiction over time. Analysis of PSC subscales showed that a significant decline in management commitment and priority, and communication (marginally) in relation to employee psychological health, within the non-harmonised group underpinned these effects. We noted no significant overall PSC change across the harmonised jurisdictions, with the exception that participation and consultation in relation to employee psychological health significantly increased. Results imply that without harmonisation the PSC levels reduced. Future research should seek detailed information regarding policy implementation, regulator perspectives and employer data to compliment results from the PSC-12.
\end{abstract}

Keywords: Psychosocial safety climate, PSC-12 tool, policy intervention, psychosocial risks, policy evaluation, workplace psychological health 


\section{Introduction}

Growing evidence indicates that psychosocial risks are a serious issue in modern organisations, and a major challenge for employees, managers, occupational health and safety experts, and policy-makers (European Agency for Safety and Health at Work (EUOSHA), 2012; Leka, Cox, \& Zwetsloot 2008). Work-related psychosocial risk factors refer to the social and relational aspects of work design that have the potential to produce detrimental effects on employee psychological (e.g., stress, burnout, depression) and physical health (e.g., musculoskeletal disorders, cardiovascular disease) (McTernan, Dollard, \& LaMontagne, 2013; Dollard et al., 2012). Psychosocial risks include bullying and harassment, emotional job demands, work intensification, job insecurity, long work hours, role conflict, and low work autonomy and co-worker support (EU-OSHA, 2012). Exposure of employees to psychosocial risks has severe adverse effects on organisational productivity (e.g., through decreased employee performance, sickness absence, employees' compensation), and contributes to economic loss at a broader societal level (e.g., greater public health costs) (Dollard et al., 2012). In Australia, depression alone costs employers approximately AU $\$ 8$ billion per annum as a result of sickness absence and presenteesim, with AU $\$ 693$ million per annum of this cost due to job strain and bullying (McTernan et al., 2013).

Within the literature it is widely acknowledged that national policy directed towards the elimination or minimisation of risks to employee health present both a foundation and a catalyst for the cultivation of healthy psychosocial work environments (LaMontagne, 2003; Leka et al., 2008). For instance, the European Risk Observatory Report (EU-OSHA, 2012) revealed that legislated policy duties and employee requests were fundamental drivers for addressing health and safety matters (including psychosocial risks), which highlights the need for strong regulatory frameworks. Overall, national policy frameworks are regarded by stakeholders and researchers as the most effective strategy for improving accountability and empowering inspectors to initiate specific constructive workplace changes (LaMontagne, 2003). However, there is a lack of research that explores the effectiveness of national work health and safety (WHS) policy approaches, as well as a dearth of defined frameworks by which to systematically assess policy impact over time via benchmarks (Leka, Jain, Zwetsloot, \& Cox, 2010). Assessing policy is particularly crucial for the management of psychosocial risks due to their complexity, severity and lesser degree of policy attention in comparison to physical WHS risks (Johnstone, Quinlan, \& McNamara, 2008). More specifically, tracking policy effectiveness is fundamental in assessing progress and identifying gaps for future development that promotes healthy psychosocial work environments. This is of particular importance in current times of change, as the global context of work is being increasingly shaped by principles of neo-liberalism, evident through the growth in economic policies that support globalisation and greater deregulation of the market (Bramble, 2014; Coffey \& Marston, 2013; EU-OSHA, 2012; Gagliardi, Marinaccio, Valenti, \& lavicoli, 2012). 
The current paper addresses the substantial gap in WHS policy research by investigating the impact of a WHS policy intervention. We propose that Psychosocial Safety Climate (PSC) theory provides an appropriate framework within which to evaluate the impact of policy that intends to address psychosocial factors at work. PSC refers to a specific facet of organisational climate that concerns employee psychological health and safety. PSC is largely determined by management priority for employee psychological health in contrast to productivity concerns (Dollard \& Bakker, 2010). There is significant empirical evidence that shows PSC is a reliable leading 'upstream' indicator of psychosocial working conditions and work health outcomes (Dollard \& Bailey, 2014; Zadow \& Dollard, 2016). As such, rather than focusing on lagged indicators, establishing PSC levels is sufficient to infer downstream effects, and we propose that its use in evaluation is best practice in terms of validity, reliability and efficiency (Dollard \& Bailey 2014). We trial the concept and measurement tool, the PSC-12 and its benchmarks, in an investigation of an Australian policy intervention that aimed to address both physical and psychosocial risks, strengthen the protection and promotion of total employee health, and increase legislative consistency across jurisdictions (i.e. harmonisation).

\section{Work Health and Safety Policy Interventions}

Increasing awareness and global dissemination of research which highlights the psychological harm associated with psychosocial risk factors has driven major developments in WHS public policy (Ertel et al., 2010; Leka, Jain, lavicoli, Vartia, \&, Ertel, 2011; Levi, 2000). Legislated WHS policy has a critical function in driving organisations to accept responsibility for meeting specific requirements pertinent to employee health, predominantly through delineating specific legislated duties and regulations. Furthermore legislated WHS policy also provides a robust framework for WHS regulators to monitor workplace compliance in protecting employee health and safety and impose improvements (Johnstone et al., 2008). In addition to asserting juridical regulations, WHS policy also comprises less stringent voluntary approaches such as guidance material to help organisations on a more practical level (LaMontagne, 2003). Greater attention to psychological health in WHS policy has also preceded the creation of various psychosocial risk management tools that aim to translate statutory obligations into practice within organisations (Potter, Fattori, \& Dollard, 2016).

Nevertheless, WHS policy approaches are in different stages of evolution across the world and reflect varying degrees of comprehensiveness surrounding employee health protection and promotion. For example, in certain countries such as the United States of America (USA), WHS policies focus mainly on physical safety concerns, and therefore predominantly emphasise occupational health from a physical aspect, in terms of occupational diseases like asbestosis, cancers, noise induced hearing loss from exposure to physical hazards injuries. However, policies established in other world regions, such as Scandinavia, make explicit reference to the protection of both employees' physical and psychological health through addressing both physical and psychosocial risk factors (Engman, 2003). A considerable amount of progress has been achieved in Europe due to legislative and 
institutional developments such as the Framework Directive 89/391/EEC. In addition, a number of policy initiatives aimed at promoting psychosocial risk management have also been initiated with increased stakeholder involvement through social dialogue (see Leka, Jain, lavicoli, Di Tecco, , 2015 for a review of European policy on psychosocial risks and mental health in the workplace). Some EU member states, including Sweden, Italy and the Czech Republic have even introduced their own national regulatory occupational health and safety $(\mathrm{OSH})$ frameworks. Furthermore, many other countries have implemented nonregulatory policy approaches to endorse the management of psychosocial risks.

\section{Evaluating the Impact of WHS Policy}

Despite the widely acknowledged support for national policy interventions, and the immense time and resources devoted to their development and implementation, assessment of effectiveness has been largely overlooked in the academic literature (Leka et al., 2008; LaMontagne, 2003). In particular, many developments in national WHS policy have not been evaluated in relation to changes in perceptions of employees in relation to how their organisation protects their health. The lack of evaluative research is commonly attributed to difficulties in acquiring representative and time-appropriate national data, and obtaining reliable enterprise level indicators that will infer policy impact over time (WHO, 2004). Even in Europe, where occupational health policy approaches are deemed the most globally advanced, there is a notable deficiency in systematic evaluation of the effectiveness of national policy interventions (Leka et al., 2010, 2015; Leka et al., 2008) (see also Kompier, 2004; Murphy \& Sauter, 2004; Schaufeli \& Kompier, 2001; Taris, van der Wal, \& Kompier, 2010). Some progress has been made by researchers involved in the innovative policyorientated research programme, the European Framework for Psychosocial Risk Management (PRIMA-EF), with a series of national reviews to determine the policy impact on health and safety, and economic and social effects (see Leka et al., 2008). In addition, there have been several studies focused on evaluating the implementation process of the UK's national policy HSE Management Standards to address work stress within organisations (Mellor et al., 2011).

National surveillance systems on psychosocial risks and outcomes are an important means of monitoring the effectiveness of interventions and policies as highlighted by Dollard, Skinner, Tuckey, and Bailey (2007). National surveillance data is regarded as best practice for determining changes in the profile of work and psychosocial risk factors, as well as monitoring the progression and effectiveness of policy (Dollard et al., 2007). For example, within Europe, the European Survey of Enterprises on New and Emerging Risks (ESENER) 1 conducted in 2009 and the ESENER 2 in 2014 (EU-OSHA, 2017) have been instrumental in ascertaining a detailed understanding of work-related health at a national and industry level. ESENER 1 focused on interviews with the most experienced person in charge of health and safety in the workplace and the employee health and safety representatives. In ESENER 2 interviews were conducted with the person with the most knowledge about health and safety in the organisation. Moreover through the European PRIMA-EF project, Roozeboom, Houtman, and can den Bossche (2008) explored best practice indicators and 
provided future recommendations based on the European Working Conditions Survey (EWCS; European Foundation for the Improvement of Living and Working Conditions, 2002). Roozeboom et al. (2008) stated that whilst the EWCS indicator list provides a solid basis for assessing psychosocial risk management, the survey also lacks indicators focused on preventative action.

Overall the majority of WHS research, particularly originating from the Asia Pacific region, comprises studies that investigate individual and organisational interventions (although these studies are still limited) or theoretical relationships. The lack of national policy intervention evaluation research is echoed in a comprehensive review for Safe Work Australia (2013), which asserted that there is minimal information on the effectiveness of any regulatory interventions in Australia. An additional review by the Australian Safety and Compensation Council (2008) also established that there was little attempt to monitor the efficacy of $\mathrm{OSH}$ instruments, namely Codes of Practice and guidance material. Consequently, the impact or effectiveness from these policy approaches on the experiences of Australian employees is yet to be known.

As a result, two main questions arise. First, what is the extent of impact of WHS policy interventions? Second, what is the best measure to determine change as a result of policy interventions? It is vital that research focuses on assessing effectiveness of national WHS policy through best practice frameworks, in order to provide a solid evidence base on which to propose developments that will close the gap between policy objectives and organisational practice (Leka et al., 2008; Leka et al., 2010; Murphy \& Sauter, 2004). Furthermore, tools and evaluation frameworks are essential for continual monitoring of changes to national policy and employee health, and to provide a base to evaluate further policy developments. Investigation into whether the current policy approaches are rigorous enough to protect and promote employee psychological health, as well as the identification of potential areas for policy development, is particularly relevant to overcome complex challenges associated with managing and regulating psychosocial risk factors within the organisation (Levi, 2005). Challenges include: 1) confusion amongst stakeholders surrounding the lexis and nature of risks to psychological health; 2) a poorly defined organisational case for prioritising and managing these risks; and 3) insufficient or adequate resources and expertise to transform these legislative obligations into enterprise practice (Langenhan, Leka, \& Jain, 2013; Leka, Van Wasenhove, \& Jain, 2015; Leka et al., 2010; Leka et al., 2011).

\section{PSC-12: An Indicator of Policy Effectiveness within the Jurisdiction}

Psychosocial Safety Climate refers to the value that the organisation places on employee psychological health and wellbeing compared to productivity concerns, and is expressed through the enacted policies, practices and procedures that are designed to protect and promote psychological health (Dollard \& Bakker, 2010; see Zadow and Dollard (2016) for comprehensive overview). The PSC-12 tool is a 12-item scale comprised of four components: 1) management commitment and support for stress prevention; 2) 
management priority for employee psychological health compared to productivity; 3) the degree and effectiveness of communication systems; and 4) participation and consultation at all levels of the organisation regarding psychological safety matters (Zadow \& Dollard, 2016). PSC is conceived as a property of the organisation. To assess an organisations' PSC, levels are typically derived through aggregating scores based on the individual perceptions to the level of the organisation or work group.

PSC theory (Dollard \& Bakker, 2010; Dollard \& Karasek, 2010; Dollard \& McTernan, 2011; Dollard, 2012), extends well-established work stress theories such as the Job DemandsResources (JD-R) model (Demerouti, Nachreiner, Bakker, \& Schaufeli, 2001), the Job Demand-Control (JD-C) Model (Karasek, 1979) and the Effort-Reward Imbalance model (ERI) (Owen, Bailey, \& Dollard, 2016). While these work stress theories elaborate different aspects of job design that are stressful, PSC theory suggests that the source of the problem emanates at the organisational level. Managerial values influence policies and practices, such as resource distribution, the kinds of demands placed on employees, and the kinds of workplace behaviours that will be rewarded or not (Law, Dollard, Tuckey Dormann ,2011; see Zadow \& Dollard, 2016 for comprehensive overview). As a result, PSC is a root cause of many issues such as bullying and harassment, and precedes job demands and job resources, and is therefore a predictor of risk factors and the ensuing health and economic outcomes (Dollard, 2012). Evidence about PSC can be used by organisations and regulatory agencies to create safer working environments at lower risk of employee mental and physical health harm. For these reasons, PSC is purported to be a best-practice means of evaluating policy and represents major progress in the field of work-related national surveillance. Since PSC is a concept that refers to enterprise level policies and practices in relation to employee health and safety, it is logical to expect that national level changes in policy may affect organisational PSC.

Importantly, the PSC-12 tool is a central component of the Australian Workplace Barometer Project (AWB; for overview see Bailey \& Dollard, 2014) of national surveillance of workplace psychosocial risks. Research shows that PSC can predict national health outcomes and indicate where more resources and interventions should be invested. Hall, Dollard and Coward (2010) empirically validated the psychometric properties of the PSC-12 (see Hall, Dollard, \& Coward, 2010) using confirmatory factor analysis and then validated the scale in a representative sample of Australia employees $(n=398)$. They also showed in a third organisational study ( $n=16$ teams, 106 health care workers) that PSC demonstrated climate like psychometric properties. Bailey, Dollard and Richards (2014) found PSC was a significant predictor of job strain and symptoms of depression. PSC benchmarks have been established using data from 4000 employees using the PSC-12 (Hall, Dollard, \& Coward, 2010). The PSC-12 has a range of scores from $12-60$ with low risk PSC at 41 or above and high risk PSC at 37 or below benchmarks for job strain and depression (Bailey, Dollard, \& Richards, 2015).

Strong empirical evidence confirms that PSC is a multilevel construct that is evident at the national, enterprise and individual level and is a reliable and valid predictor of other 
psychosocial risks (a 'cause of the causes'), employee health and productivity. For instance there is evidence that PSC at a national level is associated with employee health, in a study across 31 European countries (Dollard \& Karasek, 2010; Dollard \& Neser, 2013). As a lead indicator it is a more effective predictor of work conditions, employee health and productivity in comparison to lag indictors such as workers' compensation claims (Law, et al., 2011). The strong evidence supporting the predictive function of PSC in the work stress process implies that the PSC measure is potentially a valid tool to capture the influence of national policy in changes and impact of national work health and safety policy on employees' perception of psychological health.

\section{Overview of the Australian Work Health and Safety Policy Framework and Intervention}

\section{Policy Framework}

The Australian WHS policy framework is comprised of three distinct layers that constitute the formal legislation. At the highest level, the WHS Act establishes the general duties that are placed on various parties involved in the conduct of work. The WHS Act is supported by a framework of legislative instruments, including WHS Regulations and various approved Codes of Practice, which prescribe the duties and provide guidance to employers on how to meet the requirements of the Act (Safe Work Australia, 2012). Overall the WHS Act has the core objective to protect the health, safety and welfare of individuals who may be affected by work in any sector. The Regulations and Codes of Practice describe with greater specificity the practical action to be taken to ensure compliance (Stewart, 2013).

At the second level, the WHS Regulations stipulate mandatory requirements for duty holders to meet as specified under the WHS Act (Safe Work Australia, 2012). The Regulations focus on various aspects pertaining to work health and safety including issues surrounding worker representation and participation and managing WHS risks and general workplace arrangements. In addition, the Regulations address hazardous work, such as falls, driving, electrical safety, as well as plant and structures, construction work, hazardous chemicals, asbestos, major hazard fatalities, and mines. At the third level, Codes of Practice generally provide two main functions: 1) they provide evidence that a duty under the WHS laws has been met and are therefore admissible in court; and 2) they are a point of reference for inspectors when enforcing the legislation. In addition to these three layers, policy makers have also created voluntary guidance material to supplement these regulatory instruments in order to provide further explanation on how workplaces can meet compliance with the legal requirements (Dunn, 2012).

\section{National WHS Policy Intervention in Australia}

In June 2011 Australian WHS laws underwent substantial changes with a new Model WHS 'policy package', to reinvigorate and standardise WHS obligations. Yet the enactment of the Model WHS laws occurred at slightly different times across participating jurisdictions. Despite the intent to standardise WHS legislation nationally, the jurisdictions of Western 
Australia and Victoria did not adopt the Model legislation at this time. The process of standardising policy approaches across Australia at this time is referred to as 'harmonisation'. The main reason for harmonisation was that whilst some legislation reflected similarities, there were substantial differences in terminology, standards and penalties across jurisdictions. These variations meant employees across jurisdictions had differing levels of legal protection despite experiencing comparable risk factors. Another issue was that employers who had multiple businesses across Australia were bound by varying standards and means of enforcement. As such, compliance with the legal requirements was complex and expensive. Also although some jurisdictions clearly recognised the protection of health, safety and welfare (e.g., the South Australian Occupational Health Safety and Welfare (OHSW) Act, 1986), the focus was largely on the prevention of recognised occupational diseases. Therefore, in 2008, the Workplace Relations Ministers' Council (WRMC), representing all Ministers of the jurisdictions with responsibility for the regulation of WHS, decided that model legislation would be the most effective way to achieve harmonisation and reinvigoration of the WHS laws (for greater detail see Johnstone, 2008).

Under the WHS Model policy a major development was that health is now legally defined as including both physical and psychological health (Dollard et al., 2012). However it should be mentioned that this was already the case in Victoria (a non-harmonised state not included in this study). Furthermore, both Victoria and Western Australia have their own approaches for addressing employee psychological health. Yet, organisations operating under the relevant harmonised jurisdictions now have explicit legal obligations to eliminate or minimise work-related risks to physical and psychological health, and to "be given the highest level of protection against harm to their health, safety and welfare from hazards and risks arising from work, as far as is reasonably practicable" (Work Health \& Safety Act, 2011, p. 8). In addition to the Model WHS Act (2011), Safe Work Australia also released Model Regulations, various Codes of Practice and Guidance material to assist with managing risks to both physical and psychological health.

\section{Evaluation of WHS Policy Changes in Australia: The Current Study}

This paper is an evaluation of the impact of regulatory WHS policy interventions across Australian enterprises as perceived by employees. The evaluation used the organisational indicator, the PSC-12, as a framework to assess jurisdiction PSC levels pre and post harmonisation. The objective was to determine whether a stronger legislated focus on mitigating risks to both physical and psychological health - implemented in the process of harmonisation - corresponded with significantly higher levels of PSC. The study uses representative national data, derived through Australia's leading method of national surveillance for work-related issues, the Australian Workplace Barometer (AWB) project. We aimed to explore any differences in PSC levels in jurisdictions that participated in the policy intervention in comparison to the jurisdiction that did not participate. Given the push and efforts for harmonisation across Australia, we would anticipate that greater consistency and focus on total health correspond with increased PSC levels. 


\section{Method}

\section{Participants and Procedure}

The AWB tool uses a longitudinal survey design encompassing three waves of data from 2009 to 2014-15. Participants were recruited randomly from the Australian Electronic White Pages (in all three waves) and a directory of Australian mobile phone numbers (in the third wave, see Dal Grande et al., 2016). Repeat and new participants were sent letters informing them of the study purpose and the interview procedure (see Dollard \& Bailey, 2014 for detailed sampling process).

Not all states and territories were involved in AWB data collection at each time point. To maximise matched comparative data before and after harmonisation in 2012, we used data pre-harmonisation from repeat surveys in WA $(n=804)$ and NSW $(n=725)$ in 2010, as well as from new 2011 surveys in TAS $(n=416)$, NT $(n=170)$, SA $(n=1043)$ and ACT $(n=225)$. Post-harmonisation data was collected in 2014-15 and matched to participants in the states and territories, NSW $(n=697)$, WA $(n=700)$, SA $(n=723)$, ACT $(n=242)$, TAS $(n=307)$, NT $(n=164)$. Data from Queensland $(n=708)$, and Victoria ( $n=701$ ) was collected for the first time in 2014-15 but was not suitable for preand post- analysis. In sum, we matched data from NSW, SA, ACT, TAS, and NT (all harmonised) and WA (not harmonised) over two time waves (2010/2011 and 2014/15). Using the latest Australian Bureau of Statistics (ABS, 2010) Labour Force Survey, weighting was applied to the data to ensure the sample was representative, in terms of age and gender, of the populations of the respective states and territories.

\section{Measures}

\section{Psychosocial Safety Climate}

Psychosocial Safety Climate was measured using the PSC-12 (see Appendix A), a 12 item questionnaire encompassing four sub-scales: Management commitment, management priority, organisational communication, and participation (Hall, Dollard, \& Coward, 2011). Each sub-scale consists of three questions with responses scored on a five-point Likert scale, ranging from 1 ("strongly disagree") to 5 ("strongly agree"). Benchmarks developed by Bailey et al. (2015) for PSC indicate that scores equal to or below 37 place employees at high risk for job strain and depression whereas scores equal to or above 41 are associated with low job strain and no symptoms of depression. Scores greater than 37 and less than 41 indicate that employees are at moderate risk.

\section{Analysis}

First descriptive analyses were conducted to present a visual representation of PSC levels across jurisdictions over time (see Figure 1). Since this was population based data we gathered data at the individual level, and then aggregated PSC responses from employees to the jurisdiction level, and compared average PSC scores for jurisdictions that were harmonised (NSW, SA, ACT, TAS, NT) and not harmonised (WA) by the 201415 data collection. An upward trend in PSC is indicative of positive change. To statistically 
compare changes in levels of PSC and its four components (i.e., management commitment, management priority, communication, and participation) across time in the jurisdictions before and after harmonisation we used repeated measures ANCOVAs. We compared NSW, SA, ACT, TAS, and NT (all harmonised) to WA (not harmonised) over two time waves (2010/2011 and 2014/15). We then conducted mixed ANCOVAs as the inferential statistical analyses to assert whether or not there were significant differences across the jurisdictions over time.

\section{Results}

Descriptive means and standard deviations, relevant to PSC and socio-demographic variables (i.e. age, gender, type of employment and industry) across time and jurisdictions are shown in Appendix B. In 2010/2011, 1091 participants were from jurisdictions that would be harmonised in 2012 (NSW, SA, ACT, TAS, and ACT), and 426 participants were in a jurisdiction that would not be harmonised (WA). In the harmonised jurisdictions, the majority of participants were female ( $n=613,56 \%)$, and their ages ranged from 18 to $74(M=46.89$, $S D=10.87)$. In the non-harmonised jurisdiction, the participants ages ranged from 19 to 73 $(M=48.08, S D=9.89)$, and there were slightly more females $(n=222)$.

Figure 1 shows the descriptive analysis to determine average PSC levels for separate Australian states and territories from 2010/11 to 2015 (see Figure 1), as well as labels for each data point when surveys were conducted and arrows to indicate when the harmonised WHS Act was introduced in 2012. Results showed that PSC trends varied substantially between states. While some states, such as WA and SA, initially reported PSC levels above the benchmark, others (New South Wales, Tasmania, Northern Territory) showed starting points below the ideal PSC score of 41. Although PSC results for WA remained above the benchmark over time, the most recent data collected in 2014/15 shows a downward trajectory since 2010. In contrast results for New South Wales were consistently below the benchmark but indicated improvements in PSC since 2010. For South Australian employees PSC in 2010 was in the high PSC 'low risk' range and from there displayed a steady upward trend. While the first data collection in Australian Capital territory yielded a PSC score on the benchmark threshold, their most recent data collected in 2014/15 showed a substantial decline. Tasmania showed levels of PSC in 2011 were below the benchmark with a slight decline in 2014/15. Northern Territory PSC scores in 2011 were the lowest for any jurisdication at any time point, and the most recent data showed a sharp rise, but below the ideal benchmark of 41 . The single data point for Victoria in 2014-15 shows employees in this state reported PSC levels in the 'low risk' range. In contrast PSC scores for the single Queensland data point in 2014/15 indicated scores below the benchmark. 


\section{PSC BY JURISDICTION: 2010 - 2015}

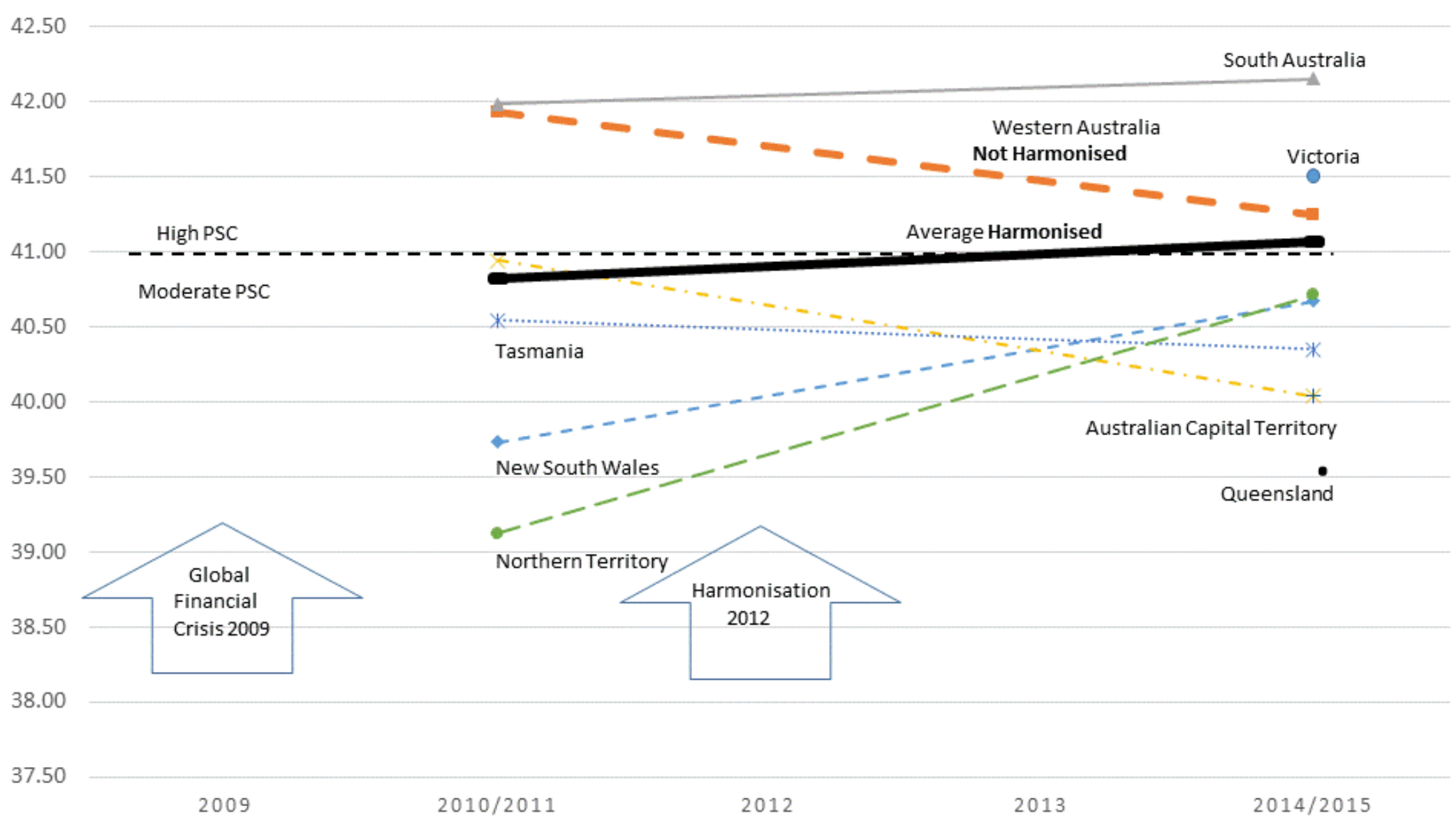

Figure 1 PSC scores comparing jurisdictions with harmonised and non-harmonised policies 


\section{Results from Inferential Analyses}

To assess differences in PSC and PSC subscales between the groups (harmonised vs not-harmonised) across time (Time 1 vs Time 2) we assessed the significance of the Group X Time interaction (see Table 1). We controlled for age and gender, and employees' industry type (dummy coded into 18 groups, while they showed no main effects, education and finance sector interacted with PSC across time so these industries were retained in the analysis).

For the global PSC measure, as expected there was a significant Group $X$ Time interaction, $F(1,1120)=4.67, p<.05$, partial eta ${ }^{2}=.03$. Using pairwise comparisons (LSD), we found the difference between the harmonised and not harmonised jurisdictions at Time $1, F(1,1104)=2.75, p=.07$, approached significance but at Time 2, $F(1,1104)$ $=.37, p$ not significant. For the harmonised group there was no difference in PSC from Time 1 to Time 2, $F(1,1104)=.66, p$ not significant. However, for the not harmonised jurisdiction there was a significant difference between Time 1 and Time 2 PSC $F(1,1104)$ $=3.89, p<.05$, with PSC levels significantly reducing over time.

As shown in Table 1, for the PSC subscales, the pattern of effects was very similar to global PSC with the exception that the Time 1 differences between the groups was significant. For the PSC subscale, management commitment, we found a significant effect of Group X Time, $F(1,1270)=4.28, p<.01$, eta $^{2}=.003$. A similar pattern of effects were found again with management priority and communication, although the Group $X$ Time effect approached significance $(p=.07)$. However given the problems associated with detecting interaction effects in the social sciences, especially with distal stimuli (see Dollard, Osborne, \& Manning, 2012) (in this case national policy) some researchers have adopted a liberal significance criterion of $p<.10$, for the interaction term (Frese, 1999). We therefore considered it likely that communication and management priority significantly varied by group across time.

In addition, for management priority and management commitment there were significant decreases in levels across Time 1 and Time 2 for the not harmonised jurisdiction $(p<$ .05). Also, there was a decrease in the communication subscale over Time 1 and Time 2 in the not harmonised jurisdiction but this only approached significance. Finally for the participation subscale, for the harmonised group, there was a significant increase in participation between Time 1 and Time $2(p<.05)$. 


\section{Table 1}

Harmonised vs not harmonised jurisdiction PSC, management commitment, management priority, communication, and participation levels across time; means, standard deviations, group $X$ time effects

\begin{tabular}{|c|c|c|c|c|c|c|c|c|c|c|c|}
\hline & & \multicolumn{2}{|c|}{ Time 1} & \multicolumn{2}{|c|}{ Time 2} & \multicolumn{2}{|c|}{ Group X Time } & \multirow{2}{*}{$\begin{array}{l}\text { Partial } \\
\text { Eta } \\
\text { Squared }\end{array}$} & \multirow{2}{*}{$\begin{array}{c}\text { Time } 1 \text { vs } \\
\text { Time } 2 \\
F\end{array}$} & \multirow{2}{*}{$\begin{array}{c}\text { Time } 1 \\
\mathrm{H} \text { vs } \mathrm{NH} \\
\mathrm{F}\end{array}$} & \multirow{2}{*}{$\begin{array}{c}\text { Time } 2 \\
\text { H VS NH } \\
F\end{array}$} \\
\hline & Group & $M$ & $S D$ & $M$ & $S D$ & $d f$ & $F$ & & & & \\
\hline \multirow[t]{2}{*}{ PSC } & Harmonised & 40.82 & 9.73 & 41.07 & 10.38 & $(1,1120)$ & $4.67^{\star}$ & .03 & 0.66 & $2.75+$ & 0.37 \\
\hline & Not Harmonised & 41.78 & 9.57 & 40.73 & 10.17 & & & & $3.89^{\star}$ & & \\
\hline Management & Harmonised & 10.58 & 2.89 & 10.60 & 2.90 & $(1,1270)$ & $4.28^{* *}$ & .003 & 0.14 & $8.78^{\star *}$ & 0.31 \\
\hline Commitment & Not Harmonised & 11.07 & 2.68 & 10.73 & 2.91 & & & & $4.83^{*}$ & & \\
\hline Management & Harmonised & 10.16 & 3.12 & 10.16 & 3.18 & $(1,1295)$ & $3.22+$ & .002 & 0.00 & $6.07^{*}$ & 0.18 \\
\hline Priority & Not Harmonised & 10.58 & 2.89 & 10.22 & 3.14 & & & & $4.36^{\star}$ & & \\
\hline \multirow[t]{2}{*}{ Communication } & Harmonised & 10.15 & 2.44 & 10.16 & 2.50 & $(1,1224)$ & $2.87+$ & .002 & 0.01 & 2.03 & 0.23 \\
\hline & Not Harmonised & 10.37 & 2.59 & 10.09 & 2.51 & & & & $3.75+$ & & \\
\hline \multirow[t]{2}{*}{ Participation } & Harmonised & 9.93 & 2.60 & 10.09 & 2.49 & $(1,1198)$ & 0.56 & .000 & $3.87^{*}$ & 0.18 & 0.13 \\
\hline & Not Harmonised & 9.98 & 2.59 & 10.08 & 2.49 & & & & 0.10 & & \\
\hline
\end{tabular}

Note.,$+ p<.10 ; *, p<.05 ; * *, p<.01 ;$ PSC, psychosocial safety climate. 


\section{Discussion}

Our study sought to evaluate the impact of harmonisation of WHS policy related to employee health in Australia. The findings show that there was a significant decrease in PSC levels for the non-harmonised jurisdiction over time. Further analysis established this was particularly related to management commitment and potentially management priority and communication. The PSC levels of the harmonised jurisdictions did not significantly change overall, yet employee participation (in psychological health and safety concerns) did significantly increase over time.

There are substantial challenges surrounding the evaluation of the effectiveness of national WHS policy interventions (Leka et al., 2010). Previous research has predominantly centred on assessing individual and organisational interventions (although limited) with little reference to the influence of national WHS policy initiatives. To counter this oversight, this paper sought to add to the literature by proposing the PSC framework, theory, assessment tool, and benchmarks, to evaluate the effects of a national WHS policy intervention using the recent Australian 'harmonisation' of WHS legislation as a policy intervention exemplar. PSC encapsulates the value that senior management places on employee well-being, particularly through the degree of communication about, and commitment to, psychological health and safety matters at work (Dollard, 2012; Dollard \& Bakker, 2010; Zadow \& Dollard, 2016). We theorised that national policy that intended to protect the psychological health and well-being of employees should influence management practices and lead to improvements in PSC in the workplace as reported by employees. However it is acknowledged that jurisdictions which did not harmonise have their own approaches for addressing employee psychological health. In order to evaluate the intervention (now involving a more comprehensive focus on total health in the policy), levels of PSC were derived from telephone interview data pre and post the policy intervention. Since not all jurisdictions adopted the harmonised policy intervention, we surmised that averaged jurisdiction differences observed in perceived organisational PSC could reasonably be attributed to the intervention.

Consistent with the theory, the jurisdiction that did not participate in the harmonisation showed a decline in PSC levels over time. For the jurisdictions that harmonised their WHS laws, PSC levels over time showed no change on average (see Figure 1 and Table 1). We found a significant Group X Time effect for the global PSC measure which indicated a significant difference in the effect slopes between the harmonised and not harmonised groups across time. The pattern of the interaction was that harmonised and not harmonised groups started off differently, and the levels of PSC decreased in the not harmonised group over time to be similar to the levels of the harmonised group. Aside from an intervention effect, there are two competing methodological and contextual explanations for the observed trends. First, seemingly by chance, the non-harmonised state was in the high PSC zone, whereas on average the harmonised jurisdictions were initially close to the PSC benchmark. So a decline in PSC for the former, and stable PSC in the latter, could be due to a regression to the mean effect. Second, from 2012 there was also a downturn in the 
mining sector, one of the largest industries in WA, the non-harmonised state. However our analysis controlled for industry type ruling out this interpretation.

When looking at the pattern of effects at the PSC sub concept level, we conclude that a decline in management commitment (and most likely management priority and communication) for psychological health and safety matters within the not harmonised group was likely to underpin the effects. For the harmonised group (across the participating jurisdiction), on average we noted no significant changes for total PSC, which may indicate that without harmonisation PSC levels over time may have reduced, so harmonisation had a stabilising effect. Moreover, there was a significant increase in participation over time. A closer examination of the jurisdictions shows that for some of them there was an increase in PSC and some a decrease so it is by no means a uniform effect. So whilst the policy intended to encourage consistency in the protection of psychological health, there appears to be differences in application of the policy and the level of regard for psychological health across jurisdictions. The reason for a lack of strong findings could be due to a range of implementation problems such as the short amount of time (2/3 years) for the policy to take effect, or a lack of awareness of the policy by organisations, and hence its lack of effect on organisational practice. Our research is consistent with the literature that affirms the difficulties in translating policy level changes into practice within organisations, which is of particular relevance for psychosocial risk management (Leka et al., 2010; Johnstone et al., 2008). There may be substantive explanations too, such as that policy itself could be lacking in strength and content to influence workplace behaviour and change in the workplace - this point is discussed in detail below.

\section{Practical and Policy Implications}

Overall the findings provide support for strengthening the message of protection and promoting psychological health across all jurisdictions, yet it is apparent that more needs to be done to increase jurisdiction PSC levels and consistency. For example, whilst there are clear obligations outlined in the WHS Act and Regulations that call for mitigation of all risk, greater attention must be given to specifying the management of psychosocial risks in future policy approaches. In general, there is great disparity between the focus and management of physical and psychosocial risks, with a tendency to focus more on targeting workplace physical risks than psychosocial risk (Australian Productivity Commission, 2010; Leka et al., 2015; Johnstone et al., 2008). As the WHS Act and Regulations are silent on specific provisions for the management of psychosocial hazards and risks, organisations are often left to work out for themselves appropriate risk assessment and control strategies. In addition, due to the lack of specificity in the law or lack of training and expertise, Australian inspectors also purport that psychosocial risks are extremely difficult to regulate due to poor clarity in the legal requirements in comparison to physical risks (Johnstone et al., 2008). Whilst Johnstone et al.'s (2008) study was conducted prior to harmonisation, outcomes are unlikely to have improved as the harmonised legislation still does not explicitly state psychosocial risks - only psychological health as the broad objective. 
Overall there is an urgent need to address the absence of explicit requirements for psychosocial risk management within the current Act and Regulation. A greater emphasis must be placed on psychosocial risks in the Act and Regulation to draw attention to the fact that the risk management processes includes psychosocial factors. WHS policy should be enhanced by adopting a greater focus on psychosocial risk management, namely through clearer regulatory frameworks, greater specificity in terminology and more practical policy material (Leka et al., 2010). Arguably the process outlined in the harmonised legislative framework is not sufficiently detailed to address psychosocial risks, as the process is not as specific as other international frameworks and literature (see PRIMA-EF as an example). In addition, there needs to be greater and more consistent guidance for duty holders and inspectors on how psychosocial risks can be regulated and managed in the organisation, for example including a Code of Practice or a Regulation.

There is also pressing need to develop further explanatory guidance and educational information that will assist organisations to meet their legislative obligations in practice in order to promote psychological health (Langenhan, Leka, \& Jain, 2013). The Act gives great legal power to Health and Safety Representatives (HSR) to monitor WHS in workplaces. These representatives receive training and have rights to pursue changes with the assistance of inspectors. As key players in implementation action within the organisation, greater education and awareness training should be funnelled to assist Health and Safety Representatives learn about psychosocial risks and their place within the legislation. Training courses could be implemented that focus on how the legislation includes both physical and psychological health, and supporting HSR form committees and systems to promote safe and healthy work within the organisation. At present, there are organisational tools (see Potter et al., 2016), which can assist workplaces achieve psychosocial risk management. It is essential that future research examines well designed interventions that establish what works in a practical way that can be implemented by organisations. Importantly, policy makers must develop strategies to promote and disseminate this evidence through Codes, Guides and supporting tools, such as the PSC-12, that can be used to audit and assess compliance and good practice (Leka \& Cox, 2008).

\section{Limitations}

This paper has several limitations that should be noted. First, we were not able to evaluate the effects of harmonisation on PSC levels in Victoria or Queensland over time due to data unavailability. Second since we had population based data we were not able to investigate organisational level change. Since the intervention effects are based on aggregate data we are unable to conclude that specific employees within the harmonised jurisdictions are better off, and can only talk in terms of averages effects (also evident by the different jurisdiction trends). Third, we acknowledge that it would be more beneficial to analyse PSC over a longer period of time to infer change. In addition, it is important to note that other measures could also be taken into consideration when assessing national employee health. Despite this, the paper is the first to attempt to examine the effects of policy in relation to psychological health in Australia using a prime organisational indicator. Due to the nature 
of the AWB data, uses repeated measures we were also able to make comparisons across jurisdictions.

\section{Future Research}

It is essential to continue national workplace psychosocial risk surveillance, as it provides evidence as to whether national and jurisdiction based PSC benchmarks are at a safe level and whether policy is having an effect (Bailey et al., 2015). Future research should focus on investigation into specific differences between each jurisdiction to help explain possible differences in levels of PSC pre and post harmonisation. For instance, conducting an indepth policy analysis similar to the recent study by Leka, Jain, lavicoli and Di Tecco (2015), will be instrumental in further determining gaps between policy and best practice approaches in managing psychosocial risks. Furthermore, it would be advantageous to investigate how regulators use principles of the Act and Regulations to enforce changes relevant to the management of psychosocial risks. To achieve this, researchers should seek the expertise of the regulators or stakeholders, which has been an approach frequently taken in Europe, especially through the PRIMA-EF project. For instance, following an in-depth study with European stakeholders, Natali, Deitinger, Rondinone and lavicoli (2008) suggested that future research should involve stakeholders in more social dialogue on psychosocial risk management in the workplace. Regulator and employer perspectives are a vital source of information by which to evaluate policy effectiveness.

Evaluation should continue to examine if policy infiltrates the enterprises and affects employees in regards to perceptions surrounding the promotion and protection of their health. Future research should also investigate the implementation and impact of policy with a context appropriate evaluation that captures various perspectives. For instance, as stated, policy should be examined as to determine how it is utilised by WHS regulators, who have the primary role to enforce change within organisations. Ultimately, it is critical to consider various perspectives in assessing the effectiveness of policy-interventions to understand the link between policy development with implementation and enterprise practice. Finally, using a multilevel analysis framework with employees situated in organisations, within jurisdictions with data appropriately referenced to the level would assist in identifying sites for improvement.

\section{Conclusions}

The PSC framework, theory and measurement tool - the PSC-12, and PSC benchmarks, is an approach to assess the impact of national work health and safety policy on employees' perception of concern about psychological health in the workplace. The current study sought to evaluate an Australian work health and safety policy intervention (harmonisation of WHS policy, with its broader definition of health), using change in perceived organisational PSC as an indicator of impact, aggregated at the jurisdiction level. The findings showed a significant Group X Time effect consistent with a positive intervention impact, with the nonharmonised state showing deterioration in PSC, and the harmonised jurisdictions showing on average no improvement (but no deterioration). It is recommended that future research 
endeavours to understand reasons for differences between jurisdictions, through gaining alternative perspectives from WHS regulators, employers, and health and safety professionals.

\section{Acknowledgements}

This project was supported by funding from the Commonwealth Government Agency Safe Work Australia, Safe Work SA, Australian Research Council Discovery Grants [DP0879007 \& DP140103429] and an Australian Research Council Linkage Grant [LP100100449].

Rachael Potter, Mikaela Owen and Tessa Bailey would also like to acknowledge the Commonwealth Government funding that they received under the Research Training Program.

\section{References}

Australian Bureau of Statistics (2010). Labour Force, Australia, Jun 2010: June key figures. Retrieved from http://www.abs.gov.au/AUSSTATS/abs@.nsf/allprimarymainfeatures/85DB64 AE72291A6ACA25777C00172EOF?opendocument.

Australian Productivity Commission (2010). Performance Benchmarking of Australian Business Regulation: OHS, Research Report, Canberra.

Australian Safety and Compensation Council (2008). A review of key characteristics that determine the efficacy of OHS instruments. Retrieved from: http://www.safeworkaustralia.gov.au/sites/SWA/about/Publications/Documents/3 33/Review_KeyCharacteristicsThatDetermineEfficacy_OHSInstruments_2008_P DF.pdf

Bailey, T.S., Dollard, M.F., \& Richards, P.A.M. (2015). A national standard for psychosocial safety climate (PSC): PSC 41 as the benchmark for low risk of job strain and depressive symptoms. Journal of Occupational Health Psychology, 20, 15-26.

Bramble, T. (2014). Australian capitalism in the neoliberal age. Marxist Left Review, 1(7), 55-95.

Coffey, B., \& Marston, G. (2013). How neoliberalism and ecological modernization shaped environmental policy in Australia. Journal of Environmental Policy \& Planning, 15(2), 179-199.

Dal Grande, E., Chittleborough, C. R., Campostrini, S., Dollard, M., \& Taylor, A. W. (2016). Pre-Survey Text Messages (SMS) Improve Participation Rate in an Australian Mobile Telephone Survey: An Experimental Study. PloS one, 11(2). 
Demerouti, E., Bakker, A. B., Nachreiner, F., \& Schaufeli, W. B. (2001). The job demands-resources model of burnout. Journal of Applied psychology, 86(3), 499.

Dollard, M. F., \& McTernan, W. (2011). Psychosocial safety climate: a multilevel theory of work stress in the health and community service sector. Epidemiology and Psychiatric Sciences, 20(04), 287-293.

Dollard, M. F., \& Neser, D. Y. (2013). Worker health is good for the economy: Union density and psychosocial safety climate as determinants of country differences in worker health and productivity in 31 European countries. Social Science \& Medicine, 92, 114-123.

Dollard, M. F., Osborne, K., \& Manning, I. (2013). A macro-level shift in modelling work distress and morale. Journal of Organizational Behavior, 34, 629-647.

Dollard, M. F., Tuckey, M. R., \& Dormann, C. (2012). Psychosocial safety climate moderates the job demand-resource interaction in predicting workgroup distress. Accident Analysis and Prevention, 45, 694-704.

Dollard, M., Bailey, T., McLinton, S., Richards, P., McTernan, W., Taylor, A., \& Bond, S. (2012). The Australian Workplace Barometer: Report on psychosocial safety climate and worker health in Australia. Canberra, Australia: Safe Work Australia.

Dollard, M.F. \& Bailey, T. S. (Eds). (2014). Australian Workplace Barometer:

Psychosocial Safety Climate and working conditions in Australia, 14-181. Samford Valley QLD; Australian Academic Press.

Dollard, M.F. (2012). Psychosocial safety climate: a lead indicator of workplace psychological health and engagement and a precursor to intervention success. In C. Biron, M. Karanika-Murray \& C. Cooper (Eds.), Improving Organizational Interventions for Stress and Well-Being Interventions: Addressing Process and Context (pp. 77-101). London: Routledge.

Dollard, M.F., \& Bakker, A.B. (2010). Psychosocial safety climate as a precursor to conducive work environments, psychological health problems, and employee engagement. Journal of Occupational and Organisational Psychology, 85, 579599.

Dollard, M.F., \& Karasek, R. (2010). Building psychosocial safety climate: Evaluation of a socially coordinated PAR risk management stress prevention study. In J. Houdmont, S. Leka \& R Sinclair (Eds). Contemporary occupational health psychology: Global perspectives on research and practice (pp. 208-234). Chichester: Wiley Blackwell.

Dollard, M.F., Skinner, N., Tuckey, M. R., \& Bailey, T. (2007). National surveillance of psychosocial risk factors in the workplace: An international overview. Work \& Stress, 21(1), 1-29. 
Dunn, C. (2012). Planning work health and safety: An introduction to best practice. $\mathrm{CCH}$ Australia, North Ryde, NSW.

Engman, C. (2003). Regulating the psychosocial issues in changing work situations. working paper 17. National Research Centre for Occupational Health Safety Regulation.

Ertel, M., Stilijanow, U., lavicoli, S., Natali, E., Jain, A., \& Leka, S. (2010). European social dialogue on psychosocial risks at work: Benefits and challenges. European Journal of Industrial Relations, 16(2), 169-183.

European Agency for Safety and Health at Work (EU-OSHA, 2012). Drivers and Barriers for Psychosocial Risk Management: An Analysis of Findings of the of the European Survey of Enterprises on New and Emerging Risks (ESENER), Publications office of the European Union, Luxembourg City. Doi: 10.2802/92077

European Agency for Safety and Health at Work (EU-OSHA, 2017). European Survey of Enterprises on New and Emerging Risks (ESENER). Retrieved from https://osha.europa.eu/en/surveys-and-statistics-osh/esener

European Foundation for the Improvement of Living and Working Conditions (Eurofound, 2002). Quality of Work and Employment in Europe: Issues and challenges. European Foundation for the Improvement of the Living and Working Conditions: Publications office of the European Union, Luxembourg City, Luxembourg.

Frese, M. (1999). Social support as a moderator of the relationship between work stressors and psychological dysfunctioning: A longitudinal study with objective measures. Journal of Occupational Health Psychology, 4, 179-192.

Gagliardi, D., Marinaccio, A., Valenti, \& lavicoli, S. (2012). Occupational safety and health in Europe: lesson from the past, challenges and opportunities for the future. Industrial Health, 50(1), 7-11.

Hall, G. B., Dollard, M. F., \& Coward, J. (2010). Psychosocial safety climate:

Development of the PSC-12. International Journal of Stress Management, 4, 353-383.

Johnstone, R. (2008). Harmonising occupational health and safety regulation in Australia: The first report of the national OHS review. Journal of Applied Law and Policy, 35-58.

Johnstone, R., Quinlan, M., \& McNamara, M. (2011). OHS inspectors and psychosocial risk factors: Evidence from Australia. Safety Science, 49(4), 547-557.

Karasek, R. A, (1979). Job demands, job decision latitude, and mental strain: Implications for job redesign. Administration Science Quarterly, 224, 285-307. 
Kompier, M. (2004). Regulations, policies and practices concerning work stress in five European countries. Work \& Stress, 8(4), 139-145.

LaMontagne, A. D. (2003). Improving occupational health \& safety policy through intervention research: Appendix A. About Safe Work Australia, 1-9.

Langenhan, M.K., Leka, S., Jain, A. (2013). Psychosocial risks: is risk management strategic enough in business and policy making? Safety and Health at Work, 4, 87-94.

Law, R. Dollard, M., Tuckey, M., Dormann, C. (2011). Psychosocial safety climate as lead indicator of workplace bullying and harassment, job resources, psychological health and employee engagement. Accident Analysis and Prevention, 43, 1782-1793.

Leka, S., Cox, T., \& Zwetsloot, G. (2008). The European framework for psychosocial risk management (PRIMA-EF). In S. Leka, \& T. Cox, (Eds), The European Framework for Psychosocial Risk Management: PRIMA-EF (pp.1-184). Nottingham, UK: IWHO Publications.

Leka, S., Jain, A., lavicoli, S., Di Tecco, C. (2015). An evaluation of the policy context on psychosocial risks and mental health in the workplace in the European Union: Achievements, challenge, and the future, BioMed Research International. Volume 2015, Article ID 213089, 1-18.

Leka, S., Jain, A., Iavicoli, S., Vartia, M. \&, Ertel, M. (2011). The role of policy for the management of psychosocial risk at the workplace in the European Union. Safety Science (49), 558-564.

Leka, S., Jain, A., Zwetsloot, G., \& Cox, T. (2010). Policy-level interventions and workrelated psychosocial risk management in the European Union. Work \& Stress, 24(3), 298-307.

Leka, S., van Wassenhove, W., \& Jain, A. (2015). Is psychosocial risk prevention possible? Deconstructing common presumptions. Safety Science, 71(1), 61-67.

Levi, L. (2000). Guidance on work-related stress: Spice of life or kiss of death?. Office for Official Publications of the European Communities.

Levi, L. (2005). Working life and mental health - A challenge to psychiatry? World Psychiatry, 4(1), 53-57.

McTernan, W. P., Dollard, M. F., \& LaMontagne, A. D. (2013). Depression in the workplace: An economic cost analysis of depression-related productivity loss attributable to job strain and bullying. Work \& Stress, 27(4), 321-338. 
Mellor, N., Mackay, C., Packham, C., Jones, R., Palferman, D., Webster, S., \& Kelly, P. (2011). 'Management standards' and work-related stress in Great Britain: progress on their implementation. Safety Science, 49(7), 1040-1046.

Murphy, L.R., \& Sauter, S.L. (2004). Work organization interventions: state of knowledge and future directions. Praventivmed, 49, 79-86.

Natali, E., Deitinger, P., Rondinone, B., \& lavicoli, S. (2008). Exploring stakeholders' perceptions on social policies, infrastructure and social dialogue in relation to psychosocial risks. In S. Leka \& T. Cox (Eds.), The European Framework for Psychosocial Risk Management (PRIMA-EF) (pp.79-114). Nottingham: I-WHO Publications.

Owen, M. S., Bailey, T. B., \& Dollard, M. F. (2016). Psychosocial safety climate as- an extension of ERI theory: Evidence from Australia. In J. Siegrist \& M. Wahrendorf (Eds.), Work stress and health in a globalized economy - The model of effortreward imbalance (pp. 189-217). Germany: Springer.

Potter, R. E., Fattori, A., \& Dollard, M. F. (2016). Organizational Tools for Psychosocial Risk Management: A Critical International Review. In Psychosocial Factors at Work in the Asia Pacific (pp. 205-224). The Netherlands: Springer International Publishing.

Roozeboom, M. B., Houtman, I., \& Van den Bossche, S. (2008). Monitoring Psychosocial Risks at work. In S. Leka \& T. Cox (Eds.), The European Framework for Psychosocial Risk Management (PRIMA-EF) (pp.79-114). Nottingham: I-WHO Publications.

Safe Work Australia. (2012). Guide to the Work Health and Safety Act. Retrieved from: http://www.safeworkaustralia.gov.au/sites/SWA/about/Publications/Documents/7 17/Guide-to-the-WHS-Act.pdf

Safe Work. (2013). The effectiveness of work health and safety interventions by regulators: A literature review. Canberra: Safe Work Australia.

Schaufeli, W., \& Kompier, M. (2001). Managing job stress in the Netherlands. International Journal of Stress Management, 8(1), 15-34.

South Australian Occupational Health Safety and Welfare Act (1986).Government of South Australia. Retrieved from:

https://www.legislation.sa.gov.au/.../occupational\%20health\%20safety\%20and\% 20wel.

Stewart, A. (2013). Stewart's Guide to Employment Law $4^{\text {th }}$ edition. The Federation Press, Leichhardt, NSW.

Taris, T. W., van der Wal, I., \& Kompier, M. (2010). Large-scale job stress interventions. In J. Houdmont, S. Leka \& R Sinclair (Eds.), Contemporary 
Occupational Health Psychology: Global Perspectives on Research and Practice, (pp. 77-97). Chichester: Wiley-Blackwell

Work Health and Safety Act. (2011). Retrieved from:

https://www.legislation.gov.au/Details/C2011A00137/rss

World Health Organization. (2004). Development of environment and health indicators for European Union countries: results of a pilot study: Report on a WHO working group meeting, Bonn, Germany 7-9 July 2004.

Zadow, A., \& Dollard, M.F. (2016). Psychosocial safety climate. In Clarke, S., Tahira, M., Probst, F., Guldenmund, F., \& Passmore, J. (Eds.). The Wiley Blackwell Handbook of the Psychology of Occupational Safety and Workplace Health (pp.414-436). UK: John Wiley \& Sons, Ltd.

\section{Appendices}

Appendix A PSC-12 items (Hall, Dollard, \& Coward, 2010)

1. In my workplace senior management acts quickly to correct problems/issues that affect employees' psychological health.

2. Senior management acts decisively when a concern of an employees' psychological status is raised.

3. Senior management show support for stress prevention through involvement and commitment.

4. Psychological well-being of staff is a priority for this organisation.

5. Senior management clearly considers the psychological health of employees to be of great importance.

6. Senior management considers psychological health to be as important as productivity.

7. There is good communication here about psychological safety issues which affect me.

8. Information about workplace psychological well-being is always brought to my attention by my manager/supervisor.

9. My contributions to resolving occupational health and safety concerns are the organisation are listened to.

10. Participation and consultation in psychological health and safety concerns in the organisation are listened to.

11. Employees are encouraged to become involved in psychological health and safety matters.

12. In my organisation, the prevention of stress involves all levels of the organisation. 
Appendix B Descriptive Results for PSC, including Means and Standard Deviations

\begin{tabular}{|c|c|c|c|c|c|c|c|c|c|c|c|c|c|c|c|}
\hline & & NSW & & WA & & $\mathrm{SA}$ & & ACT & & TAS & & NT & & VIC & QLD \\
\hline & & 2010 & $2014 / 15$ & 2010 & $2014 / 15$ & 2011 & $2014 / 15$ & 2011 & $201 / 15$ & 2011 & $2014 / 15$ & 2011 & $2014 / 15$ & $2014 / 15$ & $2014 / 15$ \\
\hline \multirow[t]{7}{*}{ Age } & $18-24$ & $\begin{array}{l}39.78 \\
(8.23)\end{array}$ & $\begin{array}{l}40.12 \\
(10.96)\end{array}$ & $\begin{array}{l}43.79 \\
(10.06)\end{array}$ & $\begin{array}{l}41.31 \\
(8.69)\end{array}$ & $\begin{array}{l}42.87 \\
(8.90)\end{array}$ & $\begin{array}{l}45.06 \\
(7.22)\end{array}$ & $\begin{array}{l}42.62 \\
(8.92)\end{array}$ & $\begin{array}{l}39.46 \\
(11.12)\end{array}$ & $\begin{array}{l}41.65 \\
(9.49)\end{array}$ & $\begin{array}{l}41.28 \\
(11.15)\end{array}$ & $\begin{array}{l}39.50 \\
(4.89)\end{array}$ & $\begin{array}{l}37.98 \\
(8.47)\end{array}$ & $\begin{array}{l}43.33 \\
(8.59)\end{array}$ & $\begin{array}{l}42.27 \\
(8.62)\end{array}$ \\
\hline & $25-34$ & 40.60 & 42.34 & 42.64 & 42.35 & 41.83 & 38.19 & 44.54 & 42.79 & 40.44 & 41.75 & 40.26 & 45.38 & 42.70 & 39.94 \\
\hline & & (9.49) & (10.57) & $(9.55)$ & (8.03) & (8.38) & (9.25) & $(6.80)$ & (7.41) & (9.99) & $(11.80)$ & (10.93) & (7.43) & (9.31) & (10.86) \\
\hline & $35-44$ & $\begin{array}{l}38.97 \\
(9.82)\end{array}$ & $\begin{array}{l}40.21 \\
(9.86)\end{array}$ & $\begin{array}{l}40.58 \\
(10.10)\end{array}$ & $\begin{array}{l}40.68 \\
(10.44)\end{array}$ & $\begin{array}{l}41.95 \\
(10.63)\end{array}$ & $\begin{array}{l}43.01 \\
(8.42)\end{array}$ & $\begin{array}{l}41.11 \\
(8.77)\end{array}$ & $\begin{array}{l}39.01 \\
(11.41)\end{array}$ & $\begin{array}{l}41.05 \\
(11.54)\end{array}$ & $\begin{array}{l}39.41 \\
(10.95)\end{array}$ & $\begin{array}{l}40.33 \\
(11.88)\end{array}$ & $\begin{array}{l}41.47 \\
(11.01)\end{array}$ & $\begin{array}{l}39.82 \\
(11.01)\end{array}$ & $\begin{array}{l}39.81 \\
(11.57)\end{array}$ \\
\hline & $45-54$ & $\begin{array}{l}39.17 \\
(10.80)\end{array}$ & $\begin{array}{l}40.58 \\
(10.04)\end{array}$ & $\begin{array}{l}40.34 \\
(10.42)\end{array}$ & $\begin{array}{l}41.14 \\
(9.79)\end{array}$ & $\begin{array}{l}40.78 \\
(9.80)\end{array}$ & $\begin{array}{l}42.66 \\
(10.07)\end{array}$ & $\begin{array}{l}38.48 \\
(10.65)\end{array}$ & $\begin{array}{l}39.47 \\
(9.35)\end{array}$ & $\begin{array}{l}39.07 \\
(11.59)\end{array}$ & $\begin{array}{l}40.78 \\
(10.81)\end{array}$ & $\begin{array}{l}36.31 \\
(1031)\end{array}$ & $\begin{array}{l}37.73 \\
(1196)\end{array}$ & $\begin{array}{l}40.80 \\
(985)\end{array}$ & 39.07 \\
\hline & $55-64$ & 38.59 & 39.08 & 39.62 & 41.36 & 41.84 & 43.39 & 36.37 & 38.64 & 39.87 & 38.38 & 37.12 & 37.13 & 40.32 & 39.96 \\
\hline & & (10.51) & (10.84) & (10.05) & (9.49) & (9.99) & $(8.40)$ & $(8.84)$ & (10.01) & (11.41) & (11.87) & (14.01) & (8.93) & (11.95) & (10.65) \\
\hline \multirow[t]{2}{*}{ Gender } & Male & $\begin{array}{l}39.62 \\
(9.94)\end{array}$ & $\begin{array}{l}41.44 \\
(9.89)\end{array}$ & $\begin{array}{l}40.84 \\
(10.28)\end{array}$ & $\begin{array}{l}41.16 \\
(9.05)\end{array}$ & $\begin{array}{l}42.08 \\
(9.80)\end{array}$ & $\begin{array}{l}41.32 \\
(9.38)\end{array}$ & $\begin{array}{l}42.18 \\
(8.38)\end{array}$ & $\begin{array}{l}40.61 \\
(10.52)\end{array}$ & $\begin{array}{l}40.98 \\
(10.13)\end{array}$ & $\begin{array}{l}39.98 \\
(11.44)\end{array}$ & $\begin{array}{l}39.50 \\
(9.25)\end{array}$ & $\begin{array}{l}41.11 \\
(9.35)\end{array}$ & $\begin{array}{l}41.70 \\
(9.69)\end{array}$ & $\begin{array}{l}40.14 \\
(10.17)\end{array}$ \\
\hline & Female & $\begin{array}{l}39.23 \\
(10.12)\end{array}$ & $\begin{array}{l}39.83 \\
(10.75)\end{array}$ & $\begin{array}{l}41.51 \\
(9.96)\end{array}$ & $\begin{array}{l}41.63 \\
(9.81)\end{array}$ & $\begin{array}{l}41.32 \\
(9.75)\end{array}$ & $\begin{array}{l}43.05 \\
(8.92)\end{array}$ & $\begin{array}{l}39.87 \\
(9.88)\end{array}$ & $\begin{array}{l}39.56 \\
(9.39)\end{array}$ & $\begin{array}{l}39.72 \\
(11.52)\end{array}$ & $\begin{array}{l}40.67 \\
(11.04)\end{array}$ & $\begin{array}{l}38.69 \\
(12.57)\end{array}$ & $\begin{array}{l}40.37 \\
(11.03)\end{array}$ & $\begin{array}{l}41.04 \\
(10.70)\end{array}$ & $\begin{array}{l}40.08 \\
(11.52)\end{array}$ \\
\hline \multirow[t]{4}{*}{ Contract } & Permanent Full- & 39.19 & 40.84 & 41.22 & 41.87 & 41.98 & 41.17 & 41.76 & 40.68 & 41.18 & 39.57 & 39.22 & 40.37 & 41.64 & 40.37 \\
\hline & time & (10.06) & $(9.97)$ & $(9.94)$ & $(9.21)$ & (10.11) & (9.56) & $(8.82)$ & $(9.52)$ & (10.28) & (10.89) & (10.85) & (10.31) & (10.25) & (11.14) \\
\hline & $\begin{array}{l}\text { Permanent Part- } \\
\text { time }\end{array}$ & $\begin{array}{l}40.16 \\
(10.20)\end{array}$ & $\begin{array}{l}39.39 \\
(11.94)\end{array}$ & $\begin{array}{l}41.37 \\
(9.62)\end{array}$ & $\begin{array}{l}39.96 \\
(10.20)\end{array}$ & $\begin{array}{l}41.22 \\
(9.12)\end{array}$ & $\begin{array}{l}42.25 \\
(8.47)\end{array}$ & $\begin{array}{l}39.29 \\
(8.89)\end{array}$ & $\begin{array}{l}38.49 \\
(12.07)\end{array}$ & $\begin{array}{l}39.19 \\
(12.41)\end{array}$ & $\begin{array}{l}39.46 \\
(11.35)\end{array}$ & $\begin{array}{l}35.80 \\
(13.14)\end{array}$ & $\begin{array}{l}41.34 \\
(8.49)\end{array}$ & $\begin{array}{l}41.53 \\
(10.67)\end{array}$ & $\begin{array}{l}40.23 \\
(9.91)\end{array}$ \\
\hline & Casual/temporary & 38.85 & 39.38 & 39.52 & 41.38 & 40.96 & 41.22 & 40.32 & 41.04 & 39.62 & 47.85 & 43.48 & 45.39 & 40.49 & 38.72 \\
\hline \multirow[t]{11}{*}{ Industry } & $\begin{array}{l}\text { Accommodation, } \\
\text { cafes and } \\
\text { restaurants }\end{array}$ & $\begin{array}{l}36.64 \\
(9.95)\end{array}$ & $\begin{array}{l}42.29 \\
(14.08)\end{array}$ & $\begin{array}{l}39.13 \\
(11.86)\end{array}$ & $\begin{array}{l}39.46 \\
(10.05)\end{array}$ & $\begin{array}{l}41.62 \\
(11.63)\end{array}$ & $\begin{array}{l}41.45 \\
(9.19)\end{array}$ & $\begin{array}{l}44.00 \\
(15.79)\end{array}$ & $\begin{array}{l}33.49 \\
(10.11)\end{array}$ & $\begin{array}{l}35.79 \\
(12.10)\end{array}$ & $\begin{array}{l}39.35 \\
(14.46)\end{array}$ & $\mathrm{N} / \mathrm{A}$ & $\begin{array}{l}34.85 \\
(9.03)\end{array}$ & $\begin{array}{l}43.52 \\
(7.08)\end{array}$ & $\begin{array}{l}40.16 \\
(11.43)\end{array}$ \\
\hline & $\begin{array}{l}\text { Agriculture, } \\
\text { forestry and } \\
\text { fishing }\end{array}$ & $\begin{array}{l}39.13 \\
(10.84)\end{array}$ & $\begin{array}{l}41.91 \\
(5.72)\end{array}$ & $\begin{array}{l}41.76 \\
(8.96)\end{array}$ & $\begin{array}{l}45.02 \\
(8.27)\end{array}$ & $\begin{array}{l}44.65 \\
(8.76)\end{array}$ & $\begin{array}{l}41.06 \\
(6.52)\end{array}$ & $\begin{array}{l}40.30 \\
(15.26)\end{array}$ & $\begin{array}{l}39.14 \\
(4.92)\end{array}$ & $\begin{array}{l}42.48 \\
(8.36)\end{array}$ & $\begin{array}{l}36.17 \\
(11.42)\end{array}$ & $\begin{array}{l}27.00 \\
(0.00)\end{array}$ & $\begin{array}{l}22.59 \\
(0.00)\end{array}$ & $\begin{array}{l}37.59 \\
(10.37)\end{array}$ & $\begin{array}{l}45.36 \\
(8.04)\end{array}$ \\
\hline & Communications & 40.84 & 37.42 & 41.43 & 39.16 & 42.29 & 40.22 & 44.07 & 39.83 & 45.80 & 34.63 & 35.5 & 37.85 & 39.49 & 37.20 \\
\hline & services & (9.02) & (10.61) & $(11.27)$ & $(8.44)$ & (8.79) & (6.83) & (8.69) & (9.19) & (13.38) & (6.47) & $(14.23)$ & (7.10) & (7.33) & $(9.66)$ \\
\hline & Construction & $\begin{array}{l}39.37 \\
(9.27)\end{array}$ & $\begin{array}{l}40.92 \\
(8.29)\end{array}$ & $\begin{array}{l}41.84 \\
(7.83)\end{array}$ & $\begin{array}{l}46.07 \\
(9.98)\end{array}$ & $\begin{array}{l}38.18 \\
(9.48)\end{array}$ & $\begin{array}{l}37.33 \\
(9.12)\end{array}$ & $\begin{array}{l}45.19 \\
(4.63)\end{array}$ & $\begin{array}{l}41.37 \\
(8.01)\end{array}$ & $\begin{array}{l}41.48 \\
(10.64)\end{array}$ & $\begin{array}{l}41.05 \\
(10.49)\end{array}$ & $\begin{array}{l}41.25 \\
(11.82)\end{array}$ & $\begin{array}{l}49.70 \\
(0.90)\end{array}$ & 42.24 & $\begin{array}{l}41.60 \\
(982)\end{array}$ \\
\hline & Cultural and & 37.89 & 42.20 & 41.90 & 34.00 & 37.61 & 29.08 & 32.77 & 35.97 & 42.33 & 46.15 & $\mathrm{~N} / \mathrm{A}$ & 44.00 & 38.76 & 45.12 \\
\hline & $\begin{array}{l}\text { recreational } \\
\text { services }\end{array}$ & (9.69) & (15.29) & $(10.61)$ & $(0.00)$ & (11.46) & (12.54) & $(11.94)$ & (41.42) & $(16.40)$ & (7.03) & & $(0.00)$ & (10.96) & (5.83) \\
\hline & Education & $\begin{array}{l}39.27 \\
(9.84)\end{array}$ & $\begin{array}{l}39.58 \\
(11.52)\end{array}$ & $\begin{array}{l}40.54 \\
(10.40)\end{array}$ & $\begin{array}{l}39.06 \\
(9.17)\end{array}$ & $\begin{array}{l}41.71 \\
(8.14)\end{array}$ & $\begin{array}{l}45.49 \\
(7.56)\end{array}$ & $\begin{array}{l}39.75 \\
(9.97)\end{array}$ & $\begin{array}{l}43.23 \\
(10.24)\end{array}$ & $\begin{array}{l}38.93 \\
(12.38)\end{array}$ & $\begin{array}{l}40.84 \\
(10.98)\end{array}$ & $\begin{array}{l}37.94 \\
(12.99)\end{array}$ & $\begin{array}{l}34.10 \\
(10.68)\end{array}$ & $\begin{array}{l}41.06 \\
(10.64)\end{array}$ & $\begin{array}{l}39.82 \\
(11.17)\end{array}$ \\
\hline & Electricity, gas & $\begin{array}{l}40.07 \\
(10.65)\end{array}$ & $\begin{array}{l}39.98 \\
(1028)\end{array}$ & $\begin{array}{l}43.86 \\
(1010)\end{array}$ & $\begin{array}{l}46.58 \\
(7.92)\end{array}$ & $\begin{array}{l}41.93 \\
(10.95)\end{array}$ & $\begin{array}{l}41.72 \\
(1070)\end{array}$ & $\begin{array}{l}44.51 \\
(13.03)\end{array}$ & $\mathrm{N} / \mathrm{A}$ & $\begin{array}{l}35.78 \\
(13.43)\end{array}$ & $\begin{array}{l}36.86 \\
(14.03)\end{array}$ & 34.97 & 46.72 & $\begin{array}{l}38.31 \\
(1161)\end{array}$ & $\begin{array}{l}38.31 \\
(1186)\end{array}$ \\
\hline & $\begin{array}{l}\text { and water su } \\
\text { Finance and }\end{array}$ & 41.20 & 45.32 & 42.80 & 43.36 & 40.35 & 37.83 & 42.26 & 38.50 & 43.92 & 39.46 & 46.93 & 33.00 & 41.49 & 43.29 \\
\hline & Insurance & (9.11) & $(9.11)$ & (9.58) & $(9.22)$ & $(9.02)$ & (9.92) & (9.05) & (11.79) & (11.91) & (13.95) & $(0.00)$ & $(0.00)$ & (9.49) & $(8.70)$ \\
\hline
\end{tabular}




\begin{tabular}{|c|c|c|c|c|c|c|c|c|c|c|c|c|c|c|}
\hline $\begin{array}{l}\text { Government } \\
\text { administration } \\
\text { and defence }\end{array}$ & $\begin{array}{l}42.71 \\
(8.95)\end{array}$ & $\begin{array}{l}40.18 \\
(9.21)\end{array}$ & $\begin{array}{l}40.55 \\
(9.25)\end{array}$ & $\begin{array}{l}39.91 \\
(8.76)\end{array}$ & $\begin{array}{l}41.73 \\
(8.79)\end{array}$ & $\begin{array}{l}44.08 \\
(8.37)\end{array}$ & $\begin{array}{l}40.59 \\
(8.60)\end{array}$ & $\begin{array}{l}40.96 \\
(10.71)\end{array}$ & $\begin{array}{l}43.59 \\
(9.26)\end{array}$ & $\begin{array}{l}36.82 \\
(7.54)\end{array}$ & $\begin{array}{l}40.09 \\
(10.20)\end{array}$ & $\begin{array}{l}39.08 \\
(8.45)\end{array}$ & $\begin{array}{l}46.76 \\
(9.06)\end{array}$ & $\begin{array}{l}39.14 \\
(11.87)\end{array}$ \\
\hline $\begin{array}{l}\text { Health and } \\
\text { community } \\
\text { services }\end{array}$ & $\begin{array}{l}38.82 \\
(11.11)\end{array}$ & $\begin{array}{l}40.82 \\
(11.97)\end{array}$ & $\begin{array}{l}41.05 \\
(9.77)\end{array}$ & $\begin{array}{l}42.42 \\
(10.55)\end{array}$ & $\begin{array}{l}41.90 \\
(10.73)\end{array}$ & $\begin{array}{l}41.70 \\
(9.63)\end{array}$ & $\begin{array}{l}37.76 \\
(10.90)\end{array}$ & $\begin{array}{l}37.56 \\
(8.84)\end{array}$ & $\begin{array}{l}39.68 \\
(10.58)\end{array}$ & $\begin{array}{l}42.18 \\
(10.36)\end{array}$ & $\begin{array}{l}36.26 \\
(12.74)\end{array}$ & $\begin{array}{l}38.58 \\
(10.54)\end{array}$ & $\begin{array}{l}40.45 \\
(11.17)\end{array}$ & $\begin{array}{l}41.54 \\
(8.90)\end{array}$ \\
\hline Manufacturing & $\begin{array}{l}39.80 \\
(10.09)\end{array}$ & $\begin{array}{l}43.63 \\
(7.39)\end{array}$ & $\begin{array}{l}42.16 \\
(8.87)\end{array}$ & $\begin{array}{l}36.71 \\
(8.20)\end{array}$ & $\begin{array}{l}41.25 \\
(11.59)\end{array}$ & $\begin{array}{l}40.15 \\
(10.50)\end{array}$ & $\begin{array}{l}42.78 \\
(9.63)\end{array}$ & $\begin{array}{l}51.00 \\
(0.00)\end{array}$ & $\begin{array}{l}38.36 \\
(8.94)\end{array}$ & $\begin{array}{l}39.97 \\
(10.60)\end{array}$ & $\begin{array}{l}50.22 \\
(38.49)\end{array}$ & $\mathrm{N} / \mathrm{A}$ & $\begin{array}{l}44.72 \\
(6.29)\end{array}$ & $\begin{array}{l}44.65 \\
(10.26)\end{array}$ \\
\hline Mining & $\begin{array}{l}40.05 \\
(8.68)\end{array}$ & $\begin{array}{l}33.78 \\
(16.70)\end{array}$ & $\begin{array}{l}41.86 \\
(11.07)\end{array}$ & $\begin{array}{l}41.26 \\
(9.31)\end{array}$ & $\begin{array}{l}46.23 \\
(6.66)\end{array}$ & $\begin{array}{l}44.49 \\
(9.14)\end{array}$ & $\mathrm{N} / \mathrm{A}$ & $\begin{array}{l}42.38 \\
(6.33)\end{array}$ & $\begin{array}{l}43.62 \\
(9.49)\end{array}$ & $\begin{array}{l}36.40 \\
(6.45)\end{array}$ & $\begin{array}{l}40.96 \\
(8.37)\end{array}$ & $\begin{array}{l}48.44 \\
(0.65)\end{array}$ & $\begin{array}{l}43.00 \\
(8.90)\end{array}$ & $\begin{array}{l}38.33 \\
(14.49)\end{array}$ \\
\hline $\begin{array}{l}\text { Personal and } \\
\text { other services }\end{array}$ & $\begin{array}{l}38.21 \\
(8.39)\end{array}$ & $\begin{array}{l}44.81 \\
(6.74)\end{array}$ & $\begin{array}{l}47.21 \\
(8.17)\end{array}$ & $\begin{array}{l}43.77 \\
(8.11)\end{array}$ & $\begin{array}{l}46.49 \\
(8.01)\end{array}$ & $\begin{array}{l}45.66 \\
(5.23)\end{array}$ & $\begin{array}{l}42.70 \\
(10.32)\end{array}$ & $\begin{array}{l}37.50 \\
(11.38)\end{array}$ & $\begin{array}{l}32.97 \\
(12.11)\end{array}$ & $\begin{array}{l}48.56 \\
(8.43)\end{array}$ & $\begin{array}{l}37.38 \\
(11.75)\end{array}$ & $\begin{array}{l}27.55 \\
(14.83)\end{array}$ & $\begin{array}{l}43.96 \\
(10.91)\end{array}$ & $\begin{array}{l}41.33 \\
(8.47)\end{array}$ \\
\hline $\begin{array}{l}\text { Property and } \\
\text { business services }\end{array}$ & $\begin{array}{l}35.18 \\
(1185)\end{array}$ & $\begin{array}{l}38.76 \\
(7.11)\end{array}$ & $\begin{array}{l}41.57 \\
(7.67)\end{array}$ & $\begin{array}{l}42.54 \\
(6.61)\end{array}$ & $\begin{array}{l}38.93 \\
(920)\end{array}$ & $\begin{array}{l}44.63 \\
(6.09)\end{array}$ & $\begin{array}{l}27.25 \\
(0.00)\end{array}$ & $\begin{array}{l}36.83 \\
(9.94)\end{array}$ & $\begin{array}{l}44.31 \\
(5.00)\end{array}$ & $\begin{array}{l}18.72 \\
(14.79)\end{array}$ & $\begin{array}{l}46.00 \\
(0.00)\end{array}$ & $\begin{array}{l}35.23 \\
(8.34)\end{array}$ & $\begin{array}{l}44.00 \\
(10.23)\end{array}$ & $\begin{array}{l}41.33 \\
(8.47)\end{array}$ \\
\hline Retail trade & $\begin{array}{l}40.33 \\
(8.58)\end{array}$ & $\begin{array}{l}38.80 \\
(9.71)\end{array}$ & $\begin{array}{l}41.01 \\
(10.40)\end{array}$ & $\begin{array}{l}40.84 \\
(7.84)\end{array}$ & $\begin{array}{l}40.16 \\
(10.02)\end{array}$ & $\begin{array}{l}41.19 \\
(9.18)\end{array}$ & $\begin{array}{l}45.32 \\
(5.53)\end{array}$ & $\begin{array}{l}46.08 \\
(8.45)\end{array}$ & $\begin{array}{l}44.31 \\
(10.27)\end{array}$ & $\begin{array}{l}45.31 \\
(11.01)\end{array}$ & $\begin{array}{l}41.83 \\
(13.06)\end{array}$ & $\begin{array}{l}44.90 \\
(11.29)\end{array}$ & $\begin{array}{l}39.98 \\
(8.72)\end{array}$ & $\begin{array}{l}39.98 \\
(9.89)\end{array}$ \\
\hline $\begin{array}{l}\text { Transport and } \\
\text { storage }\end{array}$ & $\begin{array}{l}36.37 \\
(11.49)\end{array}$ & $\begin{array}{l}42.38 \\
(9.21)\end{array}$ & $\begin{array}{l}33.44 \\
(12.72)\end{array}$ & $\begin{array}{l}37.64 \\
(8.87)\end{array}$ & $\begin{array}{l}43.53 \\
(9.03)\end{array}$ & $\begin{array}{l}42.75 \\
(8.81)\end{array}$ & $\begin{array}{l}38.74 \\
(14.07)\end{array}$ & $\begin{array}{l}46.08 \\
(8.45)\end{array}$ & $\begin{array}{l}35.02 \\
(20.77)\end{array}$ & $\begin{array}{l}38.94 \\
(11.75)\end{array}$ & $\begin{array}{l}37.63 \\
(11.88)\end{array}$ & $\begin{array}{l}47.92 \\
(5.32)\end{array}$ & $\begin{array}{l}41.98 \\
(8.72)\end{array}$ & $\begin{array}{l}38.54 \\
(12.18)\end{array}$ \\
\hline Wholesale trade & $\begin{array}{l}33.88 \\
(10.72)\end{array}$ & $\begin{array}{l}43.72 \\
(1.76)\end{array}$ & $\begin{array}{l}43.37 \\
(12.41)\end{array}$ & $\begin{array}{l}43.13 \\
(5.08)\end{array}$ & $\begin{array}{l}47.37 \\
(7.18)\end{array}$ & $\begin{array}{l}41.80 \\
(13.27)\end{array}$ & $\mathrm{N} / \mathrm{A}$ & $\mathrm{N} / \mathrm{A}$ & $\begin{array}{l}47.55 \\
(14.67)\end{array}$ & $\begin{array}{l}50.00 \\
(0.00)\end{array}$ & $\begin{array}{l}42.24 \\
(0.00)\end{array}$ & $\begin{array}{l}47.00 \\
(0.00)\end{array}$ & $\begin{array}{l}37.33 \\
(11.13)\end{array}$ & $\begin{array}{l}33.78 \\
(11.02)\end{array}$ \\
\hline Other & $\begin{array}{l}39.87 \\
(10.46)\end{array}$ & $\begin{array}{l}42.65 \\
(6.96)\end{array}$ & $\begin{array}{l}38.79 \\
(9.37)\end{array}$ & $\begin{array}{l}36.00 \\
(0.00)\end{array}$ & $\mathrm{N} / \mathrm{A}$ & $\begin{array}{l}45.92 \\
(3.22)\end{array}$ & $\mathrm{N} / \mathrm{A}$ & $\begin{array}{l}38.39 \\
(8.46)\end{array}$ & $\mathrm{N} / \mathrm{A}$ & $\begin{array}{l}20.11 \\
(10.39)\end{array}$ & $\mathrm{N} / \mathrm{A}$ & $\begin{array}{l}48.00 \\
(0.00)\end{array}$ & $\begin{array}{l}40.33 \\
(9.46)\end{array}$ & $\begin{array}{l}36.96 \\
(12.73)\end{array}$ \\
\hline
\end{tabular}

